\title{
Variasi Morfologi Bambu Tali [Gigantochloa apus (Schult.F.) Kurz.] pada berbagai ketinggian tempat di Sub Daerah Aliran Sungai Pelus
}

\author{
Tria Fauzi Prabandani Hakim, Pudji Widodo, dan Eming Sudiana \\ Fakultas Biologi Universitas Jenderal Soedirman, Purwokerto \\ e-mail: dhanihakim19@gmail.com
}

\begin{abstract}
A study on the morphological variation of tali bamboo [Gigantochloa apus (Schult.f.) Kurz] has been conducted at various altitudesof Sub Watershed Pelus Banyumas, Central Java. This study was aimed at determining the morphological variations in relation to altitudes above sea levels. The method used was survey with stratified sampling. The variables measured included culm diameter, culm internodelength, culm sheath length and width, ovate-triangular blade lengthand width, leaf bladelength and width,stem color and hairs, and altitude. The results of this study indicated that the altitudinal difference effect some morphological characteristics of tali bamboos such as: 1) green young seedling with black hairs found at 200-299 m and 300-399 m asl. 2) morphological variations are effected by altitude. Tali bamboo grows optimally at the altitude of 400 to $499 \mathrm{~m}$ asl. The results of regression analysis showed that the altitude has a relatively close correlation with somes of morphological character of tali bamboo.
\end{abstract}

Keywords: Tali bamboo, morphology, altitude, environmental faktors

\begin{abstract}
Abstrak
Penelitian tentang variasi morfologis bambu tali[Gigantochloa apus (Schult.f.) Kurz] telah dilakukan pada ketinggian yang bervariasi dari daerah aliran sungai pelus Banyumas Jawa Tengah. Penelitian ini bertujuan untuk mengetahui variasi morfologis dalam hubungannya dengan ketinggian tempat di atas permuykaan laut. Metode yang digunakan adalah survai dengan pengambilan sam pel secara berstrata. Variabel yang diamati meliputi diameter buluh, panjang ruas, panjang dan lebar pelepah, panjang dan lebar helaian menyegitiga di ujung buluh, panjang dan lebar daun, warna batang dan rambut-rambut, dan ketinggian tempat. Hasil penelitian ini menunjukkan bahwa: 1) anakan muda hijau dengan ramput hitam ditemukan pada ketinggian 200-299 m dan 300-399 m dpl. 2) karakter morfologis bambu tali dipengaruhi oleh ketinggian tempat. Bambu tali tumbuh secara optimal pada ketinggian antara $400-500 \mathrm{~m}$ di atas permukaan laut. Hasil analisis regresi menunjuk kan bahwa ketinggian tempat mempengaruhi beberapa karakter morfologis bambu tali.
\end{abstract}

Kata kunci: Bambu tali, morfologi, ketinggian tempat, faktor lingkungan

\section{Pendahuluan}

Bambu tali (Gigantochloa apus (Schult.f.) Kurz) termasuk spesies bambu dengan rumpun simpodial, rapat, dan tegak. Masyarakat pedesaan, khususnya di pulau Jawa dan Bali, telah menanam bambu tali (Widjaja, 2001). Bambu tali biasanya ditanam di pinggiran sungai, batas desa, dan lereng perbukitan dari dataran rendah sampai dataran tinggi $( \pm 1.300 \mathrm{~m} \mathrm{dpl})$ (Dransfield dan Widjaja, 1995). Bambu tali banyak ditemukan di pinggiran sungai Pelus.

Sungai Pelus merupakan salah satu sungai yang terdapat di kabupaten Banyumas yang berada pada ketinggian 24$810 \mathrm{~m}$ dpl. Mata air sungai ini berada di lereng selatan gunung Slamet. Sungai Pelus juga memperoleh pasokan air dari beberapa anak sungai, diantaranya dari sungai Belot, sungai Lirip, sungai Pangkon, dan sungai Bener (Abdullah, 2006).

Pertumbuhan bambu tali dipengaruhi oleh kondisi lingkungan. Faktor lingkungan yang berkaitan dengan syarat tumbuh bambu meliputi iklim dan jenis tanah. Unsurunsur iklim itu meliputi sinar matahari, suhu, ketinggian tempat, curah hujan, dan kelembaban (Nugraheni, 2000). Meskipun demikian, ketika tumbuh-an berada pada lingkungan yang kurang optimal, maka tumbuhan akan melakukan adaptasi. Salah satu fenomena adaptasi yang dimiliki tumbuhan adalah plastisitas.

Plastisitas merupakan reaksi tumbuhan terhadap perubahan lingkungan yang sering disertai dengan modifikasi berbagai organnya (Yuliani dan Raharjo, 2009). Salah satu faktor lingkungan yang dapat mempengaruhi variasi morfologi 
tumbuhan adalah ketinggian tempat. Perbedaanketinggian tempat menyebabkan terjadinya perbedaan suhu lingkung-an. Suhu lingkungan akan menurun sebesar $0,6^{\circ} \mathrm{C}$ pada setiap kenaikan $100 \mathrm{~m}$ dpl (Goltenboth et al., 2006). Suhu lingkungan merupakan salah satu faktor penting, karena mempunyai pengaruh terhadap proses metabolisme (Arief, 1994).

Berdasarkan latar belakang tersebut maka perlu diadakan penelitian terhadap variasi morfologi bambu tali di sub daerah aliran sungai Pelus dengan berbagai ketinggian tempat.

Tujuan penelitian adalah: 1) mengetahui berbagai variasi morfologi bambu tali pada berbagai ketinggian tempat di atas permukaan laut di pinggiran sungai Pelus. 2) mengetahui ketinggian tempat di atas permukaan laut yang optimal bagi pertumbuhan bambu tali.Penelitian ini diharapkan dapat memberi-kan informasi mengenai variasi morfologi bambu tali di pinggiran sungai Pelus sebagai akibat adanya perbedaan ketinggian tempat di atas permukaan laut, sehingga data yang diperoleh akan memberikan sumbangan pemikiran dan tambahan informasi bagi dunia ilmu pengetahuan.

\section{Metode}

Penelitian ini menggunakan metode survei. Teknik pengambilan sampel dilakukan secara stratified random sampling. Pengambilan sampel penelitian dilaksanakan di pinggiran sungai Pelus pada ketinggian 100-199 m dpl (lokasi I), 200-299 m dpl (lokasi II), 300-399 m dpl (lokasi III), 400-499 m dpl (lokasi IV), 500-599 m dpl (lokasi V), 600-699 m dpl (lokasi VI), dan 700-799 m dpl (lokasi VII). Sungai Pelus secara geografis terletak antara $7^{\circ} 18,378^{\prime}$ LS sampai $7^{\circ} 25,546^{\prime}$ LS dan $109^{\circ} 14,529^{\prime}$ BT sampai $109^{\circ} 16,189^{\prime} \mathrm{BT}$, dan berada pada ketinggian 24-810 m dpl, serta memiliki panjang kurang lebih $28 \mathrm{~km}$.

Pembuatan herbarium dilakukan di Laboratorium Taksonomi Tumbuhan Fakultas Biologi Universitas Jenderal Soedirman, Purwokerto. Variabel terikat yang diamati dalam penelitian ini adalah variasi morfologi bambu tali sedangkan variabel bebas yang diamati antara lain ketinggian tempat di atas permukaan laut, suhu udara, kelembaban udara, $\mathrm{pH}$ tanah, dan intensitas cahaya matahari.
Data yang diperoleh dianalisis secara deskriptif mengenai morfologi dan habitat. Besarnya pengaruh ketinggian tempat terhadap variasi morfologi bambu tali dianalisis menggunakan analisis varians (ANOVA) dengan Rancangan Ack Lengkap diulang sebanyak 3 kaliyang dilanjutkan dengan uji Wilayah Berganda Duncan (DMRT), sedangkan keeratan hubungan antara ketinggian tempat dengan morfologi bambu dianalisis menggunakan regresi. Model regresi yang digunakan adalah sebagai berikut:

$$
Y=a+b X
$$

Untuk mengetahui model regresi terbaik maka model regresi linear tersebut dibandingkan dengan model regresi kuadratik dan kubik dengan model persamaan regresi sebagai berikut:

$$
\begin{aligned}
& Y=a+b_{1} X+b_{2} X^{2} \text { dan } \\
& Y=a+b_{1} X+b_{2} X^{2}+b_{3} X^{3} \\
& \text { Keterangan: } \\
& Y \quad \text { : morfologi bambu tali. } \\
& \text { a : konstanta regresi. } \\
& \mathrm{b}, \mathrm{b}_{1}, \mathrm{~b}_{2}, \mathrm{~b}_{3} \quad: \text { :koefisien peubah bebas. } \\
& \mathrm{X} \quad \text { : ketinggian tempat. }
\end{aligned}
$$

\section{Hasil dan pembahasan}

Seluruh data kualitatif karakter morfologi bambu tali pada hasil pengamatan diperoleh adanya persamaan di seluruh lokasi penelitian. Pertumbuhan buluh bambu tali termasuk tipe simpodial. Rebung hijau tertutup rambut hitam, ditemukan hanya pada ketinggian 200-299 m dpl dan 300-399 $\mathrm{m}$ dpl. Buluh bentuk silinder, hijau, terdapat rambut pada permukaan buluh dengan warna coklat. Pelepah buluh kuat, coklat, tertutup rambut coklat tua; daun pelepah buluh bentuk segitiga, terlekuk balik, dengan ujung luncip. Daun hijau, tepi daun rata, dengan ujung luncip, bagian atas halus dan hijau, bagian bawah kasar dan hijau pucat; tangkai daun hijau.

Hasil penelitian tampaknya sesuai dengan hasil penelitianPriyambodo (2010), bambu tali memiliki sistem percabangan akar simpodial. Buluh hijau tua, permukaan kasar tanpa rambut. Pelepah buluh coklat muda, dengan bentuk menyerupai trapesium; daun pelepah buluh berbentuk seperti segitiga, terlekuk balik. Daun berbentuk lanset, ujung daun runcing, tepi daun rata, dengan permukaan bagian atas berwarna hijau tua dan bagian bawah hijau muda, tekstur daun lemas, dengan tangkai 
daun berwarna hijau, tulang daun hijau kekuningan.

Widjaja (2001) menyebutkan bahwa bambu tali memiliki rumpun simpodial, rapat dan tegak. Rebung hijau tertutup bulu coklat dan hitam. Buluh lurus dan hijau. Pelepah buluh tidak mudah luruh, tertutup bulu hitam atau coklat; daun pelepah buluh terlekuk balik, menyegitiga dengan pangkal sempit. Daun bagian bawah permukaan daun agak berbulu. Menurut Dransfield dan Widjaja (1995) bambu tali memiliki rumpun simpodial. Buluh tegak, hijau keabu-abuan atau hijau kekuningan. Pelepah buluh bentuk menyerupai trapesium, kuat, hijau dan tertutup rambut coklat gelap ketika muda, coklat dan tanpa rambut ketika dewasa. Daun berbentuk lanset, bagian permukaan bawah sedikit berambut ketika muda.

Hasil analisis varians (ANOVA) menunjukkan terdapat 2 data kuantitatif karakter morfologi bambu tali (ketebalan dinding buluh dan panjang tangkai daun) yang tidak dipengaruhi oleh ketinggian tempat pada lokasi penelitian, sedangkan 8 karakter morfologi yang lainnya (diameter buluh, panjang ruas buluh, panjang dan lebar pelepah buluh, panjang dan lebar daun pelepah buluh, serta panjang dan lebar daun) dipengaruhi oleh ketinggian tempat di atas permukaan laut.

\section{Diameter Buluh}

Diameter buluh bambu tali pada penelitian ini berkisar antara 5,6-8,4 cm. Diameter buluh pada penelitian ini berukuran lebih besar dibandingkan dengan diameter buluh hasil penelitian Priyambodo (2010), dengan ukuran diameter buluh bambu tali pada ketinggian $64 \mathrm{~m}$ dpl berkisar antara 3,2-3,5 cm.

Tabel 1. Nilai Rataan Diameter Buluh pada Berbagai Ketinggian Tempat

\begin{tabular}{cc}
\hline $\begin{array}{c}\text { Ketinggian Tempat } \\
\text { (m dpl) }\end{array}$ & $\begin{array}{c}\text { Diameter Buluh } \\
\text { (cm) }\end{array}$ \\
\hline $100-199$ & $5,6^{\mathrm{a}}$ \\
$200-299$ & $6,7^{\mathrm{ab}}$ \\
$300-399$ & $7,0^{\mathrm{ab}}$ \\
$400-499$ & $8,4^{\mathrm{c}}$ \\
$500-599$ & $7,5^{\mathrm{bc}}$ \\
$600-699$ & $6,5^{\mathrm{ab}}$ \\
$700-799$ & $6,0^{\mathrm{ab}}$ \\
\hline
\end{tabular}

Keterangan : Angka yang diikuti huruf yang sama tidak berbeda nyata pada DMRT $5 \%$.
Hasil analisis varians menunjukkan adanya pengaruh yang signifikan antara ketinggian tempat terhadap diameter buluh (Tabel 1). Adanya pengaruh ketinggian tempat terhadap diameter buluh diduga dikarenakan adanya perbedaan suhu dan intensitas cahaya matahari pada setiap lokasi penelitian. Diameter buluh bambu tali pada penelitian ini tumbuh optimal di ketinggian 400-499 $\mathrm{m}$ dpl dengan suhu udara $28^{\circ}-29^{\circ} \mathrm{C}, \mathrm{pH}$ tanah $6,6-6,8$, kelembaban udara $60-61 \%$, dan intensitas cahaya matahari 57.000-72.900 lux. Hasil analisis regresi menunjukkan bahwa antara ketinggian tempat di atas permukaan laut dengan panjang ruas buluh bambu tali memiliki hubungan yang erat dengan nilai signifikansi ( $p$ ) sebesar 0,001 $(p<0,05)$. Pola hubungan tersebut mengikuti pola hubungan kuadratik dengan model persamaan regresi $\mathrm{Y}=3,724+0,019 \mathrm{X}+$ $0,00002 X^{2}$ dengan koefisien determinasi $\left(R^{2}\right)$ sebesar 0,57 (Gambar 2).

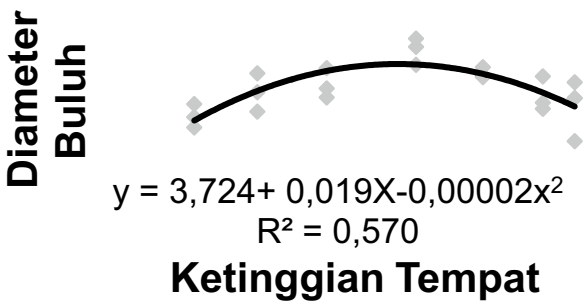

Gambar 2. Hubungan antara Ketinggian Tempat dengan Diameter Buluh

\section{Panjang Ruas Buluh}

Panjang ruas buluh bambu tali pada penelitian ini berkisar antara 34,2-44 cm. Hasil penelitian ini tampaknya sesuai dengan hasil penelitian Priyambodo (2010) yang mendapatkan panjang ruas buluh bambu tali pada lokasi penelitian dengan ketinggian tempat $64 \mathrm{~m}$ dpl berkisar antara $38-45 \mathrm{~cm}$.

Tabel2. Nilai Rataan Panjang Ruas Buluh pada Berbagai Ketinggian Tempat

\begin{tabular}{cc}
\hline $\begin{array}{c}\text { Ketinggian Tempat (m } \\
\text { dpl) }\end{array}$ & $\begin{array}{c}\text { Panjang Ruas } \\
\text { Buluh }(\mathrm{cm})\end{array}$ \\
\hline $100-199$ & $34,2^{\mathrm{a}}$ \\
$200-299$ & $36,1^{\mathrm{ab}}$ \\
$300-399$ & $35,8^{\text {ab }}$ \\
$400-499$ & $44,0^{\mathrm{c}}$ \\
$500-599$ & $39,9^{\text {bc }}$ \\
$600-699$ & $39,1^{\text {abc }}$ \\
$700-799$ & $39,0^{\text {abc }}$ \\
\hline
\end{tabular}


Keterangan : Angka yang diikuti huruf yang sama tidak berbeda nyata pada DMRT $5 \%$.

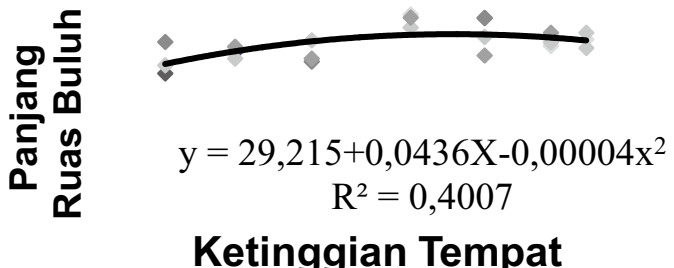

Gambar 3. Hubungan antara Ketinggian Tempat dengan Panjang Ruas Buluh

Hasil analisis varians menunjukkan bahwa ketinggian tempat berpengaruh signifikan terhadap panjang ruas buluh (Tabel 2). Adanya pengaruh ketinggian tempat terhadap panjang ruas buluh diduga dikarenakan adanya perbedaan suhu dan intensitas cahaya matahari pada setiap lokasi penelitian. Ruas buluh bambu tali pada penelitian ini tumbuh optimal di ketinggian 400-499 $\mathrm{m}$ dpl dengan suhu udara $28^{\circ}-29^{\circ} \mathrm{C}, \mathrm{pH}$ tanah $6,6-6,8$, kelembaban udara $60-61 \%$, dan intensitas cahaya matahari 57.000-72.900 lux. Hasil analisis regresi menunjukkan bahwa antara ketinggian tempat di atas permukaan laut dengan panjang ruas buluh bambu tali memiliki hubungan yang erat dengan nilai signifikansi ( $p$ ) sebesar 0,009 $(p<0,05)$. Pola hubungan tersebut mengikuti pola hubungan kuadratik dengan model persamaan regresi

$Y=29,215+0,0436 X+0,0004 X^{2}$

dengan koefisien determinasi $\left(R^{2}\right)$ sebesar 0,4007 (Gambar 3).

\section{Ketebalan Dinding Buluh}

Tabel3. Nilai Rataan Ketebalan Dinding Buluh pada Berbagai Ketinggian Tempat

\begin{tabular}{cc}
\hline $\begin{array}{c}\text { Ketinggian } \\
\text { Tempat (m dpl) }\end{array}$ & $\begin{array}{c}\text { Ketebalan Dinding } \\
\text { Buluh (cm) }\end{array}$ \\
\hline $100-199$ & $1,6^{\mathrm{a}}$ \\
$200-299$ & $1,9^{\mathrm{a}}$ \\
$300-399$ & $2,0^{\mathrm{a}}$ \\
$400-499$ & $1,7^{\mathrm{a}}$ \\
$500-599$ & $1,8^{\mathrm{a}}$ \\
$600-699$ & $2,4^{\mathrm{a}}$ \\
$700-799$ & $1,5^{\mathrm{a}}$ \\
\hline
\end{tabular}

Keterangan: Angka yang diikuti huruf yang sama tidak berbeda nyata pada DMRT $5 \%$.
Ketebalan dinding buluh bambu tali pada penelitian ini berkisar antara 1,5-2,4 $\mathrm{cm}$. Ketebalan dinding buluh pada penelitian ini berukuran lebih besar dibandingkan dengan hasil penelitian Priyambodo (2010). Menurut Priyambodo (2010) ketebalan dinding buluh bambu tali pada lokasi penelitian dengan ketinggian $64 \mathrm{~m}$ dpl berkisar antara 0,4-0,6 cm. Hasil analisis varians dengan nilai signifikansi $(p)$ sebesar $0,55(p>0,05)$ menunjukkan bahwa ketinggian tempat tidak berpengaruh signifikan terhadap ketebalan dinding buluh (Tabel 3). Hal tersebut diduga karena adanya perbedaan kerapatan tanaman pada setiap lokasi penelitian. Dugaan ini didasarkan atas pernyataan Gardner et al. (1991) bahwa kerapatan tanaman merupakan faktor yang mempengaruhi pertumbuhan karena penyerapan energi matahari oleh permukaan daun sangat menentukan pertumbuhan tanaman. Jika kondisi tanaman terlalu rapat sehingga cahaya tidak dapat mengenai sebagian besar tubuh tanaman dapat menekan perkembangan vegetatif akibat laju fotosintesis yang rendah.

\section{Panjang Pelepah Buluh}

Tabel 4. Nilai rataan panjang pelepah buluh pada berbagai ketinggian tempat

\begin{tabular}{cc}
\hline $\begin{array}{c}\text { Ketinggian } \\
\text { Tempat }(\mathrm{m} \mathrm{dpl})\end{array}$ & $\begin{array}{c}\text { Panjang Pelepah } \\
\text { Buluh }(\mathrm{cm})\end{array}$ \\
\hline $100-199$ & $20,7^{\mathrm{a}}$ \\
$200-299$ & $23,9^{\mathrm{abc}}$ \\
$300-399$ & $25,8^{\mathrm{abc}}$ \\
$400-499$ & $31,5^{\mathrm{c}}$ \\
$500-599$ & $29,4^{\mathrm{bc}}$ \\
$600-699$ & $24,9^{\mathrm{abc}}$ \\
$700-799$ & $21,8^{\mathrm{ab}}$ \\
\hline
\end{tabular}

Keterangan : Angka yang diikuti huruf yang sama tidak berbeda nyata pada DMRT $5 \%$.

Panjang pelepah buluh bambu tali pada penelitian ini berkisar antara 20,7-31,5 $\mathrm{cm}$. Panjang pelepah buluh pada penelitian ini lebih bervariasi dibanding hasil penelitian Priyambodo (2010), menunjukkan bahwavariasipanjang pelepah buluh bambu tali pada ketinggian $64 \mathrm{~m}$ dpl berkisar antara $30-33 \mathrm{~cm}$.

Hasil analisis varians menunjukkan bahwa ketinggian tempat di atas permukaan 
laut berpengaruh signifikan terhadap panjang pelepah buluh (Tabel 4). Demikian juga dengan hasil analisis regresi. Hasil analisis regresi menunjukkan adanya hubungan yang sangat erat antara ketinggian tempat di atas permukaan laut dengan panjang pelepah buluh dengan nilai signifikansi $(p)$ sebesar $0,003(p<0,05)$. Pola hubungan tersebut mengikuti pola hubungan kuadratik dengan model regresi $Y$ $=12,039+0,0805 X+0,00009 X^{2}$ dan dengan koefisien determinasi $\left(R^{2}\right)$ sebesar 0,468 (Gambar 4). Adanya pengaruh ketinggian tempat di atas permukaan laut terhadap panjang pelepah buluh diduga berhubungan dengan adanya perbedaan suhu udara dan intensitas cahaya matahari. Suhu udara dan intensitas cahaya matahari pada setiap stasiun penelitian terdapat perbedaan. Panjang pelepah buluh bambu tali pada penelitian ini tumbuh optimal di ketinggian $400-499 \mathrm{~m}$ dpl dengan suhu udara $28^{\circ}-29^{\circ} \mathrm{C}$, $\mathrm{pH}$ tanah 6,6-6,8, kelembaban udara 60-61, dan intensitas cahaya matahari 57.00072.900 lux.
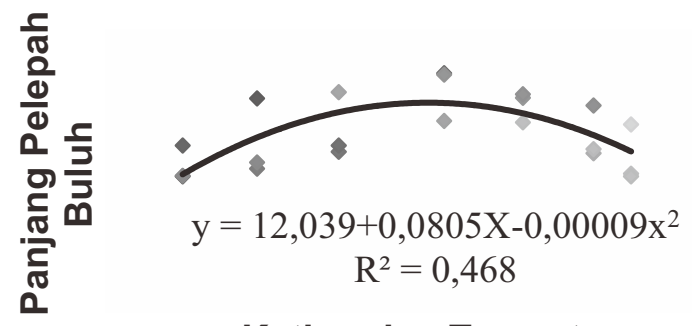

Ketinggian Tempat

Gambar 4. Hubungan antara Ketinggian Tempat dengan Panjang Pelepah Buluh

\section{Lebar Pelepah Buluh}

Tabel 5. Nilai Rataan Lebar Pelepah Buluh pada Berbagai Ketinggian Tempat

\begin{tabular}{cc}
\hline $\begin{array}{c}\text { Ketinggian Tempat } \\
\text { (m dpl) }\end{array}$ & $\begin{array}{c}\text { Lebar Pelepah } \\
\text { Buluh (cm) }\end{array}$ \\
\hline $100-199$ & $26,1^{\mathrm{a}}$ \\
$200-299$ & $29,9^{\mathrm{abc}}$ \\
$300-399$ & $34,7^{\text {ab }}$ \\
$400-499$ & $39,4^{\mathrm{c}}$ \\
$500-599$ & $35,8^{\mathrm{bc}}$ \\
$600-699$ & $32,7^{\mathrm{abc}}$ \\
$700-799$ & $27,4^{\mathrm{abc}}$ \\
\hline
\end{tabular}

Keterangan : Angka yang diikuti huruf yang sama tidak berbeda nyata pada DMRT $5 \%$.
Lebar pelepah buluh bambu tali pada penelitian ini berkisar antara 26,1-39,4 cm. Lebar pelepah buluh pada penelitian ini lebih bervariasi dibanding hasil penelitian Priyambodo (2010), menunjukkan bahwavariasilebar pelepah buluh bambu tali pada ketinggian $64 \mathrm{~m}$ dpl berkisar antara 30$37 \mathrm{~cm}$.

Hasil analisis varians menunjukkan bahwa ketinggian tempat berpengaruh signifikan terhadap lebar pelepah buluh (Tabel 5). Demikian juga dengan hasil analisis regresi. Hasil analisis regresi menunjukkan adanya hubungan yang sangat erat antara ketinggian tempat di atas permukaan laut dengan lebar pelepah buluh dengan nilai signifikansi $(p)$ sebesar 0,001 $(p<0,05)$. Pola hubungan tersebut mengikuti pola hubungan kuadratik dengan model persamaan regresi $Y=15,345+0,1025 X$ $0,0001 X^{2}$ dan dengan koefisien determinasi $\left(R^{2}\right)$ sebesar 0,5041 (Gambar 5). Hal ini dikarenakan suhu dan intensitas cahaya matahari pada setiap lokasi penelitian berbeda. Lebar pelepah buluh bambu tali pada penelitian ini tumbuh optimal di ketinggian 400-499 $\mathrm{m}$ dpl dengan suhu udara $28^{\circ}-29^{\circ} \mathrm{C}$, pH tanah 6,6-6,8, kelembaban udara $60-61 \%$, dan intensitas cahaya matahari 57.000-72.900 lux.
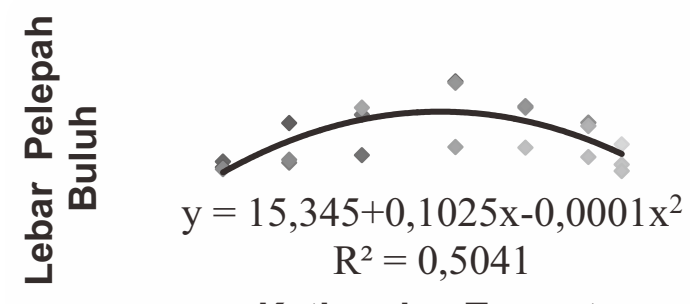

Ketinggian Tempat

Gambar 5. Hubungan antara Ketinggian Tempat dengan Lebar Pelepah Buluh

\section{Panjang Daun Pelepah Buluh}

Panjang daun pelepah buluh bambu tali pada penelitian ini berkisar antara $7-13,1 \mathrm{~cm}$. Panjang daun pelepah buluh pada penelitian ini berukuran lebih besar dibandingkan dengan hasil penelitian Priyambodo (2010), menunjukkan bahwapanjang daun pelepah buluh bambu tali pada ketinggian $64 \mathrm{~m}$ dpl berkisar antara 6-9 $\mathrm{cm}$. 
Tabel6. Nilai Rataan Panjang Daun Pelepah Buluh pada Berbagai Ketinggian Tempat

\begin{tabular}{cc}
\hline $\begin{array}{c}\text { Ketinggian } \\
\text { Tempat (m dpl) }\end{array}$ & $\begin{array}{c}\text { Panjang Daun } \\
\text { Pelepah Buluh } \\
(\mathbf{c m})\end{array}$ \\
\hline $100-199$ & $7,0^{\mathrm{a}}$ \\
$200-299$ & $9,5^{\mathrm{ab}}$ \\
$300-399$ & $7,5^{\mathrm{a}}$ \\
$400-499$ & $13,1^{\mathrm{c}}$ \\
$500-599$ & $12,3^{\mathrm{bc}}$ \\
$600-699$ & $6,7^{\mathrm{ab}}$ \\
$700-799$ & $11,2^{\mathrm{bc}}$ \\
\hline
\end{tabular}

Keterangan : Angka yang diikuti huruf yang sama tidak berbeda nyata pada DMRT $5 \%$.

Hasil analisis varians menunjukkan bahwa ketinggian tempat berpengaruh signifikan terhadap panjang daun pelepah buluh (Tabel 6). Hasil analisis regresi menunjukkan adanya hubungan yang sangat erat antara ketinggian tempat di atas permukaan laut dengan panjang daun pelepah buluh dengan nilai signifikansi $(p)$ sebesar 0,01 $(p<0,05)$. Pola hubungan tersebut mengikuti pola hubungan kuadratik dengan model regresi $Y=4,4362+0,026 X-$ $0,00002 X^{2}$ dan dengan koefisien determinasi $\left(R^{2}\right)$ sebesar 0,3848 (Gambar 6 ). Adanya pengaruh antara ketinggian tempat di atas permukaan laut dengan panjang daun pelepah buluh diduga sebagai akibat dari adanya perbedaan suhu dan intensitas cahaya matahari pada setiap lokasi penelitian. Panjang daun pelepah buluh bambu tali tumbuh optimal pada ketinggian 400-499 $\mathrm{m}$ dpl dengan suhu udara $28^{\circ}-29^{\circ} \mathrm{C}, \mathrm{pH}$ tanah $6,6-6,8$, kelembaban udara $60-61 \%$, dan intensitas cahaya matahari 57.000-72.900 lux.

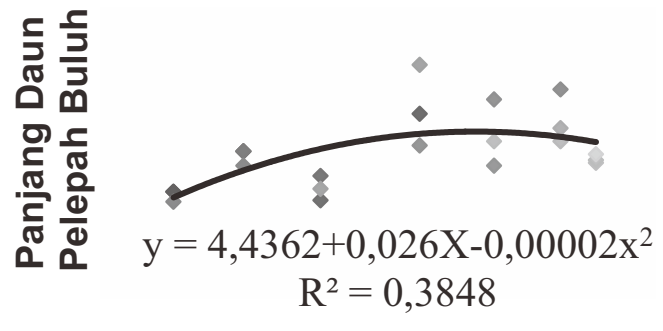

Ketinggian Tempat

Gambar 6. Hubungan antara Ketinggian Tempat dengan Panjang Daun Pelepah Buluh

\section{Lebar Daun Pelepah Buluh}

Tabel7. Nilai Rataan Lebar Daun Pelepah Buluh pada Berbagai Ketinggian Tempat

\begin{tabular}{cc}
\hline $\begin{array}{c}\text { Ketinggian } \\
\text { Tempat (m dpl) }\end{array}$ & $\begin{array}{c}\text { Lebar Daun } \\
\text { Pelepah Buluh (cm) }\end{array}$ \\
\hline $100-199$ & $2,8^{\mathrm{a}}$ \\
$200-299$ & $3,0^{\mathrm{a}}$ \\
$300-399$ & $2,8^{\mathrm{a}}$ \\
$400-499$ & $4,7^{\mathrm{b}}$ \\
$500-599$ & $4,6^{\mathrm{b}}$ \\
$600-699$ & $3,4^{\mathrm{ab}}$ \\
$700-799$ & $4,6^{\mathrm{b}}$ \\
\hline
\end{tabular}

Keterangan : Angka yang diikuti huruf yang sama tidak berbeda nyata pada DMRT $5 \%$.

Lebar daun pelepah buluh bambu tali pada penelitian ini berkisar antara 2,8-4,7 $\mathrm{cm}$. Lebar daun pelepah buluh pada penelitian ini tampaknya lebih besar dibanding hasil penelitian Priyambodo (2010),yakni pada ketinggian tempat $64 \mathrm{~m}$ dpl berkisar antara 1,5-2,0 cm.

Hasil analisis varians dengan nilai signifikansi $(p)$ sebesar $0,04 \quad(p<0,05)$ menunjukkan bahwa ketinggian tempat berpengaruh signifikan terhadap lebar daun pelepah buluh (Tabel 7). Hal ini dikarenakan suhu dan intensitas cahaya matahari pada setiap lokasi penelitian berbeda. Lebar daun pelepah buluh bambu tali pada penelitian ini tumbuh optimal di ketinggian 400-499 m dpl dengan suhu udara $28^{\circ}-29^{\circ} \mathrm{C}, \mathrm{pH}$ tanah 6,6 6,8 , kelembaban udara $60-61 \%$, dan intensitas cahaya matahari 57.000-72.900 lux.

\section{Panjang Daun}

Tabel 8. Nilai Rataan Panjang Daun pada Berbagai Ketinggian Tempat

\begin{tabular}{cc}
\hline $\begin{array}{c}\text { Ketinggian } \\
\text { Tempat }(\mathbf{m} \text { dpl) }\end{array}$ & Panjang Daun (cm) \\
\hline $100-199$ & $32,7^{\mathrm{a}}$ \\
$200-299$ & $35,9^{\mathrm{ab}}$ \\
$300-399$ & $35,2^{\mathrm{ab}}$ \\
$400-499$ & $41,5^{\mathrm{c}}$ \\
$500-599$ & $38,7^{\mathrm{bc}}$ \\
$600-699$ & $36,0^{\mathrm{ab}}$ \\
$700-799$ & $37,9^{\mathrm{bc}}$ \\
\hline
\end{tabular}

Keterangan : Angka yang diikuti huruf yang sama tidak berbeda nyata pada DMRT $5 \%$. 
Rataan panjang daun bambu tali di lokasi penelitian berkisar antara 32,7-41,5 cm. Panjang daun pada penelitian ini lebih bervariasi dibanding hasil penelitian Priyambodo (2010), menunjukkan bahwavariasipanjang daun bambu tali pada ketinggian $64 \mathrm{~m}$ dpl berkisar antara 35-40 $\mathrm{cm}$. Hasil analisis varians dengan nilai signifikansi $(p)$ sebesar $0,04 \quad(p<0,05)$ menunjukkan bahwa ketinggian tempat berpengaruh signifikan terhadap panjang daun (Tabel 8). Hal ini dikarenakan suhu dan intensitas cahaya matahari pada setiap lokasi penelitian berbeda. Panjang daun bambu tali pada penelitian ini tumbuh optimal di ketinggian 400-499 m dpl dengan suhu udara $28^{\circ}-29^{\circ} \mathrm{C}$, pH tanah $6,6-6,8$, kelembaban udara $60-61 \%$, dan intensitas cahaya matahari 57.000-72.900 lux.

\section{Lebar Daun}

Tabel9. Nilai Rataan Lebar Daun pada Berbagai Ketinggian Tempat

\begin{tabular}{cc}
\hline $\begin{array}{c}\text { Ketinggian Tempat } \\
\text { (m dpl) }\end{array}$ & Lebar Daun (cm) \\
\hline $100-199$ & $4,6^{\mathrm{a}}$ \\
$200-299$ & $5,7^{\mathrm{ab}}$ \\
$300-399$ & $5,2^{\mathrm{ab}}$ \\
$400-499$ & $7,5^{\mathrm{c}}$ \\
$500-599$ & $7,3^{\mathrm{c}}$ \\
$600-699$ & $5,8^{\mathrm{ab}}$ \\
$700-799$ & $6,6^{\mathrm{bc}}$ \\
\hline
\end{tabular}

Keterangan : Angka yang diikuti huruf yang sama tidak berbeda nyata pada DMRT $5 \%$.

Lebar daun bambu tali pada penelitian ini berkisar antara 4,6-7,5 cm. Hasil penelitian ini tampaknya sesuai dengan hasil penelitian Priyambodo (2010) yang mendapatkan lebar daun bambu tali pada ketinggian $64 \mathrm{~m}$ dpl berkisar antara 6,5-8,0 $\mathrm{cm}$. Hasil analisis varians dengan nilai signifikansi $(p)$ sebesar $0,04 \quad(p<0,05)$ menunjukkan bahwa ketinggian tempat berpengaruh signifikan terhadap lebar daun (Tabel 9). Hal ini dikarenakan suhu dan intensitas cahaya matahari pada setiap lokasi penelitian berbeda. Lebar daun bambu tali tumbuh optimal pada ketinggian 400-499 m dpl dengan suhu udara $28^{\circ}-29^{\circ} \mathrm{C}$, $\mathrm{pH}$ tanah 6,6-6,8, kelembaban udara 60$61 \%$, dan intensitas cahaya matahari 57.000-72.900 lux.

\section{Panjang Tangkai Daun}

Tabel 10. Nilai Rataan Panjang Tangkai Daun pada Berbagai Ketinggian Tempat

\begin{tabular}{cc}
\hline $\begin{array}{c}\text { Ketinggian Tempat } \\
\text { (m dpl) }\end{array}$ & $\begin{array}{c}\text { Panjang Tangkai } \\
\text { Daun (cm) }\end{array}$ \\
\hline $100-199$ & $1,4^{\mathrm{a}}$ \\
$200-299$ & $1,2^{\mathrm{a}}$ \\
$300-399$ & $0,9^{\mathrm{a}}$ \\
$400-499$ & $1,0^{\mathrm{a}}$ \\
$500-599$ & $0,9^{\mathrm{a}}$ \\
$600-699$ & $1,3^{\mathrm{a}}$ \\
$700-799$ & $1,3^{\mathrm{a}}$ \\
\hline
\end{tabular}

Keterangan : Angka yang diikuti huruf yang sama tidak berbeda nyata pada DMRT $5 \%$.

Panjang tangkai daun bambu tali pada penelitian ini berkisar antara 0,9-1,4 cm. Hasil penelitian ini tampaknya sesuai dengan hasil penelitian Priyambodo (2010)yang memperolehpanjang tangkai daun bambu tali pada ketinggian $64 \mathrm{~m} \mathrm{dpl}$ berkisar antara 1,0-1,5 cm. Hasil analisis varians dengan nilai signifikansi $(p)$ sebesar $0,11 \quad(p>0,05)$ menunjukkan bahwa ketinggian tempat tidak berpengaruh signifikan terhadap panjang tangkai daun (Tabel 10). Hal tersebut diduga karena adanya perbedaan kerapatan tanaman pada setiap lokasi penelitian. Dugaan ini didasarkan atas pernyataan Gardner, et al. (1991) bahwa kerapatan tanaman merupakan faktor yang mempengaruhi pertumbuhan karena penyerapan energi matahari oleh permukaan daun sangat menentukan pertumbuhan tanaman. Jika kondisi tanaman terlalu rapat sehingga cahaya tidak dapat mengenai sebagian besar tubuh tanaman dapat menekan perkembangan vegetatif akibat laju fotosintesis yang rendah.

Tumbuhan merupakan organisme yang tidak berpindah tempat sehingga tumbuhan harus beradaptasi dengan kondisi lingkungan tempat tumbuhan tersebut tumbuh. Perbedaan kondisi lingkungan pada tempat tumbuh dapat mempengaruhi struktur, fisiologi, dan reproduksi suatu tumbuhan(Hemelda, 2012). Tumbuhan dapat menyediakan banyak bukti mengenai perubahan iklim. Hal tersebut disebabkan 
adanya korelasi antara iklim dan karakter daun. Ukuran daun dan tepi daun dapat menyediakan informasi bagi proses adaptasi tumbuhan terhadap rata-rata curah hujan dan suhu(Cox dan Moore, 1980).

Faktor-faktor iklim yang terkait secara langsung dengan ketinggian tempat di atas permukaan laut antara lain suhu, cahaya matahari, dan tekanan atmosfer(Korner, 2007). Tekanan atmosfer dan tekanan parsial dari gas-gas komponen atmosfer mengalami penurunan sekitar $11 \%$ untuk setiap kenaikan $1 \mathrm{~km}$ ketinggian tempat. Penurunan tekanan atmosfer dan tekanan parsial tersebut memberikan dampak terhadap pertukaran gas pada tumbuhan. Akan tetapi, dampak dari penurunan tekanan tersebut tidak terlalu besar dan bukan menjadi penyebab utama perubahan morfologi dari suatu populasi tumbuhan. Tekanan udara yang semakin rendah pada ketinggian tempat yang lebih tinggi menyebabkan laju pantulan panas dari matahari ke atmosfer menjadi lebih tinggi(Hemelda, 2012). Rata-rata suhu udara menurun $0,6^{\circ} \mathrm{C}$ per $100 \mathrm{~m}$ dpl kenaikan ketinggian tempat (Cox dan Moore, 1980). Akan tetapi, setiap organisme mengalami perubahan suhu yang berbedabeda. Pohon dengan batang yang tinggi mengalami perubahan suhu yang berbeda jika dibandingkan dengan semak yang tumbuh di bawah naungan (Korner, 2007). Perubahan suhu memberikan dampak yang signifikan terhadap proses fotosintesis (Cabrera et al., 1998).

Karakter vegetatif bersifat lebih plastis daripada karakter reproduktif sehingga variasi dari karakter vegetatif dapat disebabkan karena pengaruh lingkungan (Stuessy, 1990). Variasi pada organ daun dapat disebabkan adanya pengaruh dari intensitas cahaya (Hemelda, 2012). Perubahan kondisi lingkungan dapat menjadi cekaman (stress) pada tumbuhan. Faktor lingkungan yang dapat mengakibatkan stress pada tumbuhan adalah suhu, kelembaban udara, tekanan udara atmosfer, dan cahaya (Hopkins, 1999; Hemelda, 2012). Terjadinya stress dapat memberikan dampak langsung terhadap pertumbuhan dan perkembangan tumbuhan
(Wilczek et al., 2010). Oleh karena itutumbuhan akan melakukan adaptasi. Pola adaptasi dilakukan oleh tumbuhan melalui perubahan karakter morfologinya (Hopkins, 1999; Hemelda, 2012).

\section{Simpulan}

Berdasarkan hasil dan pembahasan yang telah diuraikan di atas dapat diambil kesimpulan yaitu (1) Variasi morfologi diameter buluh, panjang ruas buluh, panjang dan lebar pelepah buluh, panjang dan lebar daun pelepah buluh, serta panjang dan lebar daun pada bambu tali (Gigantochloa apus (Schult.f.) Kurz.) sangat dipengaruhi oleh ketinggian tempat di atas permukaan laut, (2) Karakter morfologi diameter buluh, panjang ruas buluh, panjang dan lebar pelepah buluh, panjang dan lebar daun pelepah buluh, serta panjang dan lebar daun pada bambu tali (Gigantochloa apus (Schult.f.) Kurz.) tumbuh optimal pada ketinggian 400-499 m dpl.

\section{Daftar Referensi}

Abdullah, S., 2006. Estimasi Daya Tampung Beban Pencemaran Organik di Daerah Aliran Sungai Pelus Banyumas Jawa Tengah. [Online] Available at: http://www. Scribd. Com/ doc/12909189/Tesis-SugengAbdullah[Accessed 24 Februari 2014].

Arief, A., 1994. Hutan Alam dan Pengaruh Terhadap Lingkungannya. Jakarta: Yayasan Obor Indonesia.

Cabrera, H. M., Rada, F. \& Cavieres, L., 1998. Effects of Temperature on Photosynthesis of Two Morphologically Contrasting Plant Species along an Altitudinal Gradient in the Tropical High Andes. Oecologia, Volume 114, pp. 145-152.

Cox, C. B. \& Moore, P. D., 1980. Biogeography: an Ecological and Evolutionary Approach. 3rd ed. New York: John Wiley \& Sons Inc.

Dransfield, S. \& Widjaja, E. A., 1995. Plant Resources of South-East Asia 7Bambu. Bogor: PROSEA Foundation.

Gardner, F. P., Pearce, R. B. \& Mitchell, R. L., 1991. Fisiologi Tanaman Budidaya. Jakarta: UI Press. 
Goltenboth, F., Timotius, K. H., Po Milan, P. \& Margraf, J., 2006. Ecology of Insular Southeast Asia the Indonesia Archipelago. 1 ed. Netherlands: Elsevier B.V.

Hemelda, N. M., 2012. Pengaruh Gradien Ketinggian terhadap Variasi Morfologi Rotan Calamus javensis Blume (Aracaceae) di Gunung Kendeng, Taman Nasional Gunung Halimun Salak, Jawa Barat, Depok: Departemen Biologi Fakultas Matematika dan IImu Pengetahuan Alam Universitas Indonesia.

Hopkins, W. G., 1999. Introduction to Plant Physiology. 2 ed. New York: John Wiley \& Sons Inc..

Korner, C., 2007. The Use of 'Altitude' in Ecological Research. Trends in Ecology and Evolution, Volume 22, pp. 569-574.

Nugraheni, E. L., 2000. Distribusi Tumbuhan Bambu di Banyumas, Purwokerto: Fakultas Biologi Universitas Jenderal Soedirman.
Priyambodo, 2010. Keanekaragaman dan Etnobotani Tumbuhan Bambu di Desa Banjaran Kecamatan Bojongsari, Purbalingga, Purwokerto: Fakultas Biologi Universitas Jenderal Soedirman.

Stuessy, T. F., 1990. Plant Taxonomy: The Systematic Evaluation of Comparative Data. New York: Columbia University Press.

Widjaja, E. A., 2001. Identikit Jenis-jenis Bambu di Jawa. Bogor: Bidang Botani Pusat Penelitian Biologi-LIPI.

Wilczek, A. M. et al., 2010. Genetic and Physiological Bases for Phonological Responses to Current and Predicted Climates. Philosophical Transactions of the Royal Society Biological Sciences, Volume 365, pp. 3129-3147.

Yuliani \& Raharjo, 2009. Panduan Praktikum Ekofisiologi. Surabaya: Laboratorium Fisiologi Tumbuhan Jurusan Biologi Fakultas Matematika dan IImu Pengetahuan Alam Uiversitas Negeri Surabaya. 